\title{
Sivistymättömyys sivistyneisyyden vastakohtana
}

\author{
Tervonen, Ilkka. 1982. Sivistymättömyys sivistyneisyyden västakohtana. Aikuiskas- \\ vatus, 2,2, 46-48. Artikkelissa tarkastellaan sivistymättömyyden ja sivistyneisyyden \\ olemusta lähtien Castrénin ja Snellmannin sivistysajatuksista päätyen länsimaisen sivi- \\ lisaation olemukseen. Kirjoittaja analysoi barbarian, edistyksen ja modernin teknolo- \\ gian sisältöjä ja olemusta ja päätyy esittämään, että traditionaaliseen sivistysajatukseen \\ sisältyy aina kriittinen elementti itsestäänselvyyksiä kohtaan.
}

Sivistykseen liittyvän sivistyneisyyden vastakohdaksi määritellään yleensä sivisstymättömyys ja asia on tällä loppuunkäsitelty. Kun viime syksynä sain tehtäväksi valmistella alustavan puheenvuoron sivistymättömyyden ongelmasta, tuntui aihe aluksi keinotekoiselta: miksi käsitellä jonkin asian negatiivista peilikuvaa eikä itse asiaa. ${ }^{1}$ Pian kuitenkin minulle selvisi, että ennakkoasenteeni oli virheellinen.

Ensimmäinen mielenkiintoinen seikka on se, että sivistykseen liittyvät ristiriidat eivät sisälly itse sivistyksen käsitteeseen siten, että voitaisiin esimerkiksi puhua toisaalta "'hyvästä', tai "oikeasta" sivistyksestä ja toisaalta "huonosta' tai 'väärästä', sivistyksestä. Tämä johtuu siitä, että ilmaus 'hyvä" tai "oikea" sivistys on itse asiasta tautologia: jo sivistyksen käsite sinänsä. pitää sisällään tuon "hyvyyden" tai "oikeellisuuden". Näin ollen "'huono" tai "väärä" sivistys on määriteltävä sivistyksen vastakohtana.

Tätä kautta joudutaankin toiseen mielenkiintoiseen kysymykseen: sivistyksen ja siihen liittyvän sivistyneisyyden negaatio on moniselitteinen. Se voi viitata ainakin kahteen asiaan, nimittäin antisivistykseen tai ei-sivistykseen. Näillä kahdella on selvä ero. Edellinen tarkoittaa sitä, että sivistymättömyys on oma itsenäinen ominaisuutensa, antisivistys. Sen sijaan jälkimmäinen tarkoittaa sivistymättömyyttä puuttuvana ominaisuutena, jonkinlaisena eisivistyksenä.

\section{Kaksi strategiaa}

Valinta näiden kahden vaihtoehdon välillä ei suinkaan ole puhtaasti spekulatiivinen. Kysymys on ratkaisusta, joka varsin pitkälle määrää sen strategian, jolla pyritään ' 'ihmisyyden jalostamiseen', kuten Zachris Castrén asian ylevästi ilmaisee. ${ }^{2}$ Jos sivistymättömyydellä ymmärretään ei-sivistyneisyyttä, on sivistystyön tehtävänä antaa puuttuva ominaisuus, tyhjiön täyttäminen. Mikäli taas sivistymättömyydellä tarkoitetaan antisivistyneisyyttä, joudutaan kamppailemaan kielteistä ominaisuutta vastaan, uimaan vastavirtaan.

Kun pyritään saattamaan Snellmanin ja Castrénin edustama sivistysajatus hieman nykyaikaisemmalle kielelle, voidaan sanoa, että sivistyneisyyden ydin on reflektoivassa asenteessa eli pyrkimyksestä tiedostaa vallitsevat itsestäänselvyydet. Ilman kykyä siirtyä normien sokeasta noudattamisesta tietoiseen toimintaan eivät laajatkaan tiedolliset ja taidolliset valmiudet muodostu sivistyneisyydeksi. Näin ollen sivistymättömyys ilmenee kyseisen kyvyn puuttumisena, mutta tämä ei merkitse tyhjiötä, ei-sivistyneisyyttä. Reflektoivan kyvyn sijalle on astunut luovuttautuminen niin omaan itseen kuin ylipäänsäkin ihmiseen nähden ulkoisille hyötynäkökohdille, lyhyesti: antisivistyneisyys.

Tälle antisivistyneisyydelle on olemassa toinenkin nimi, barbaria, mitä ei luonnollisesti 
tule samaistaa barbariaan historiallisena ilmiönä. ${ }^{3}$ Nykyisessä tilanteessa on ymmärtääkseni kehittynyt valtava epäsuhta paisuvien instrumentaalisten tietojen ja taitojen sekä toisaalta näivettyvän reflektoivan asenteen välille. Tällöin barbaria merkitsee sitä, ettei meillä ole tietoista omakohtaista suhdetta siihen, miten sivilisaatiomme luomia tietoja ja taitoja käytetään. Näin ollen sivistyspoliittisen strategian tulee mielestäni lähteä siitä, että me joudumme kamppailemaan barbariaa vastaan. Jos me filantrooppisesti kuvittelemme, että me voimme tarjota kyvyn reflektoida, tulemme pettymään. Ensinnäkin meidät torjutaan ja toiseksi tällaista kykyä ei voida siirtää.

\section{Edistyykö edistys}

Haluan korostaa, että edellä hahmoteltu ongelma ei ole luonteeltaan skolastinen. Kohta toisen maailmansodan jälkeen Ludwig Wittgenstein kirjoitti: ' Ei ole esimerkiksi mieletöntä uskoa, että tieteen ja tekniikan aikakausi merkitsee ihmiskunnan lopun alkua; että suuren edistyksen idea on sokaistumista, kuten myös ajatus totuuden lopullisesta tuntemisesta; että tieteellisessä tiedossa ei ole mitään hyvää tai toivottavaa ja että sitä tavoitteleva ihmiskunta lankeaa ansaan. Ei ole suinkaan selvää, ettei näin olisi.",4

Tänä päivänä Wittgensteinin esittämä epäily on käytännössä osoittautunut vähintäin aiheelliseksi. Juuri siksi onkin kysyttävä: mitä todistaa "edistys", joka samalla luo ihmiskunnan tuhon aineksia? Kiistatta viime vuosikymmenet ovat monessa suhteessa merkinneet rajua edistystä määrätyillä mittareilla tarkasteltuna. Taloudellinen kasvu, teknolonen kehitys jne. tarjoavat lukuisia esimerkkejä tällaisesta edistyksestä. Jos kaikki tämä, johon myös meidän tietomme ja taitomme on varsin pitkälle mukautettu, kuitenkin kääntyy ihmistä vastaan, on oikeutettua puhua antisivistyksestä, barbariasta.

Kaikki tämä provosoikin väittämään, että yksi meidän sivilisaatiomme suurimmista harhoista on sivistysharha. On todennäköistä, että perspektiivimme on vääristynyt: sivistyksen piiriin luetaan kuuluviksi asioita, jotka eivät sinne kuulu tai jotka edustavat suorastaan antisivistystä. Vaikka esimerkiksi aseteollisuudessa palvelevat tutkijat edustaisivat miten korkeata tietämisen ja taitamisen tasoa tahansa, ei heidän aikaansaannoksiaan voida laskea sivistykseen kuuluviksi.

Nykyiselle barbarialle, joka jatkuvasti on vallannut alaa, on luonteenomaista lähinnä kaksi seikkaa. Ensinnäkin omakohtaista suhdetta ei kadoteta niinkään jollekin auktoriteetille, kuten aiemmin tapahtui, vaan systeemille, persoonattomalle järjestelmälle. Toiseksi tämä barbaria on kaventanut valinnanmahdollisuuksiamme, sitonut meitä kehityssuuntaan, jossa emansipaation - vapautumisen - sijalle ovat astumassa uudet välttämättömyydet. Ensin mainittua tekijää on käsitelty suhteellisen paljon, mutta jälkimmäiseen on kiinnitetty suhteellisen vähän huomiota. ${ }^{5}$ Koska se kuitenkin mielestäni liittyy olennaisesti moderniin sivistymättömyyteen, käsittelen sitä hieman tarkemmin.

\section{Ongelmallinen mahti}

Jos me ajattelemme modernia teknologiaa, joka ei ole mullistanut vain tuotannollista toimintaa vaan myös muuta elinympäristöämme, törmäämme vaikeaan ristiriitaan, tekisi mieleni sanoa antagonismiin, sovittamattomaan ristiriitaan. Toisaalta tämä teknologia on uusine mahdollisuuksineen antanut ihmiselle ennennäkemättömän mahdin, mutta toisaalta se myös sitoo itseensä. Uusi mahti on siis ostettu sillä hinnalla, että sitoudutaan määrättyyn kehityssuuntaan.

Esimerkiksi edellisestä käynee ydinvoima. Oltiinpa sen vaarallisuudesta mitä mieltä tahansa, on selvää, että ydinvoimalat edustavat mahtavaa keskitettyä energiantuotantojärjestelmää. Jos yhteiskunta perustaa energiahuoltonsa tällaiselle ratkaisulle, lähtee se liikkeelle niin tuotannossa kuin muussakin toiminnassa paljon energiaa käyttävistä keskitetyistä ratkaisuista; ts. ratkaisu käytännössä sulkee pois ratkaisut, jotka pyrkivät energiankäytön minimointiin ja ylipäänsä hajauttamiseen.

Hyvin usein meillä on käsitys, että joka tapauksessa teknologinen kehitys edustaa sellaista edistystä, joka tarjoaa meille aikaisempaa suuremman vapauden. Ts. se kehityssuunta, johon ollaan nykyisen teknologian myötä sitouduttu, tarjoaa aikaisempaa suuremman liikkumavaran. Todennäköisesti tämä on kuitenkin harhaa: itse asiassa se tapa, jolla tämä teknologia sitoo itseensä, kaventaa meidän valinnanmahdollisuuksiamme.

Tämä ilmenee useammallakin tavalla. Ensinnäkin nykyiset ratkaisut suosivat keskitettyjä rakenteita ja niihin liittyviä kontrollijärjestelmiä. Kriitikot ovat korostaneet esimerkiksi sitä, että ydinvoiman varaan rakentava yhteiskunta muuttuu poliisivaltioksi suojellessaan elinhermojaan. Toinen ja selvästi piilevämpi ongelma on se, miten luonnonvälttämättömyydet nykyisen teknologian kautta välittyvät 
työnjaollisiksi rakenteiksi. Tähän ovat kiinnittäneet erityistä huomiota mm. Andre Gorz ja Rudolf Bahro: ${ }^{6}$ pyrkiessään luonnon muuttamiseen määrätyn teknologian avulla ihminen joutuu väistämättä näin luomaan myös määrätyn työnjaollisen rakenteen.

Meidän ongelmamme on siis se, että ensisijaisesti luontoon liittyvä välttämättömyyden valtakunta laajenee sosiaalisiin suhteisiin ja niihin liittyviin tajunnan rakenteisiin. Tästä näkökulmasta sivistymättömyys, barbaria, on tällaisesta yhteiskunnan ja luonnon symbioosista nouseviin itsestäänselvyyksiin perustuvaa tajuntaa. Koko meidän läntisen sivilisaatiomme kannalta kyseessä voi olla varsin kohtalokas ansa: hirttäydymme omaan sivistyskäsitykseemme.

\section{Ulospääsyn mahdollisuus}

Näin hahmottuu kaksi, ainakin tärkeimmiltä osin vaihtoehtoista kehityslinjaa:

1. Sivistymättömyys ymmärretään puuttuvana ominaisuutena, joka koskee ensijaisesti elämisen välineiden maailmaa. Kun perustetaan sivistyspoliittinen strategia tälle vaihtoehdolle, on sen tavoitteena tarjota tuo puuttuva ominaisuus. Lähinnä tämä strategia johtaa siihen, että sitä kautta ihminen sidotaan vallitsevaan kehityssuuntaan välttämättömyytenä.

2. Sivistymättömyys ymmärretään omana ominaisuutenaan, antisivistyksenä, joka koskee ensisijaisesti elämisen kriteereitä, sen arvoperustaa. Jos sivistyspolitiikassa lähdetään tästä vaihtoehdosta, on sen tehtävänä lähinnä pyrkimys kysyä ja auttaa ihmisiä kysymään niiden itsestäänselvyyksien luonnetta, joille sivistymättömyys rakentuu. Tätä kautta on mahdollista palauttaa välineiden maailmasta peräisin olevat välttämättömyydet takaisin tähän maailmaan.

Uskoakseni sellainen käsitys sivistyksestä ja sivistyneisyydestä, jossa ne muodostavat kriittisen tekijän suhteessa itsestäänselvyyksinä tarjottuihin teknologisiin, kaupallisiin, valtiollisiin yms. välttämättömyyksiin, on sopusoinnussa traditionaaliseen sivistysajatuksen kanssa. Lyhyesti: sivistys ei ole apologetiaa, puolestapuhumista, vaan kriittistä suhtautumista nykyisiin 'välttämättömyyksiin" ja "'totuuksiin".

\section{Viitteet}

1. Kyseessä oleva tilaisuus oli Aikuiskasvatuksen Tutkimusseuran kokous Tampereella 10.12.81.

2. Ks. esim. artikkeli Zachris Castrén, Vapaa kansansivistystyö ja yhteiskunta. Teoksessa T.I. Wuorenrinne - Viljo Kosonen (toim), Zachris Castrén, kansansivistäjä ajatustensa valossa. Otava. Helsinki 1950.

3. Esimerkiksi Dan Steinbock puhuu "'barbariasta" myös tässä epähistoriallisessa mielessä, joskin hän käyttää käsitettä paljon laaja-alaisemmin kuin tässä on tehty.

4. Wittgenstein Ludwig, 1979. Yleisiä huomautuksia. WSOY. Porvoo. Sivu 103.

5. Lähinnä tähän on viitattu kirjallisuudessa, joka jossain mielessä tarkastelee vaihtoehtoisia kehitysstrategioita. Ks. esim. E.F. Schumacher, Pieni on kaunista, ihmisen talous ihmistä unohtamatta. Tammi. Helsinki 1976.

6. Ks. esim. André Gorz, Ökologie und Politik, Beiträge zur Wachstumskrise. Rowohlt. Hamburg 1977. Rudolf Bahro, Vaihtoehto, reaalisesti olemassaolevan sosialismin kritiikkiä. Otava. Keuruu 1979. 